\title{
EFFECT OF SULPHADIMIDINE ON THE TOXICITY OF PHENOBARBITAL IN COCKERELS OF DIFFERENT AGES
}

\author{
J. ŚIMƯNEK, EVA HEGEROVÁ, JAROSLAVA KLIMEŠOVÁ and RADKA ZAVADILOVÁ \\ Department of Pharmacology and Toxicology, University of Veterinary Science, 61242 Brno
}

Received Fuly 31, 1984

\begin{abstract}
Simůnek J., Eva Hegerová, Jaroslava Klimešová and Radka Zavadilová: Effect of Sulphadimidine on the Toxicity of Phenobarbital in Cockerels of Different Ages. Acta vet. Brno, 54, 1985 : 183-187.

Acute toxicity $\left(\mathrm{LD}_{50}\right)$ of phenobarbital sodium salt administered intramuscularly alone and after premedication with sulphadimidine sodium salt (in i. $\mathrm{m}$. doses of $0.2 \mathrm{~g} / \mathrm{kg}$ body mass) given 15 or 120 minutes before phenobarbital administration was determined in cockerels aged 7, 28 and 49 days.

The acute toxicity of phenobarbital decreased with increasing age of the birds. Sulphadimidine premedication did not affect the acute phenobarbital toxicity in 7-day-old cockerels and increased it in 28- and 59-day-old birds, compared to their non-premedicated counterparts, particularly when given 15 minutes before phenobarbital administration. In 28-day-old cockerels this rise in toxicity was significant.

Observations for signs of depression within 24 hours of phenobarbital administration showed differences between the birds of the three different ages. The signs were most intense in the oldest birds and particularly in those premedicated with sulphadimidine 15 minutes before phenobarbital administration.
\end{abstract}

Gallus domesticus, $L D_{50}$ of phenobarbital, sulphadimidine premedication, age-dependence.

With increasing use of biologically active substances under modern animal production conditions the question of interactions of these substances has been gaining in importance also in veterinary care. The problem is no longer just one of interactions between drugs - typical pharmaceutical agents - but may also involve interactions of other chemical substances used to influence physiological functions of farm animals (in growth promotion, oestrus synchronization, etc.). It can therefore be expected that, unlike in the past, drugs administered for therapeutical purposes nowadays will not exert their effects on animals having no previous medication with chemical substances or long-term drug treatment but will be given to animals already affected by some other exogenous biologically active substance(s).

In the light of these considerations it is quite obvious that a large number of interactions may occur at all levels of drug action on the animal body, i.e. from the primary (pharmaceutical) phase where the pharmaceutical availability of active ingredient may be affected, over the pharmacokinetic phase with possible effects on the biological availability of active ingredient, to the pharmacodynamic phase where the effect proper of active ingredient may be affected in the process of its interaction with the corresponding receptor ( $S$ im un $\mathrm{nek} 1980$ a.o.).

The experimental work reported here was focused on one item relevant to the aforementioned problem, namely interactions of phenobarbital with sulphadimidine in view of their possible effect on phenobarbital toxicity.

Phenobarbital is the active ingredient of Sedophen ${ }^{R}$, a drug for veterinary use, which contains in addition ascorbic acid and is used to tranquilize chickens (List of Veterinary Drugs SPOFA 1983). Sulphadimidine has been the most widely used sulphonamide in the therapy of coccidiosis of chickens in our country (Vodrážka et al. 1980 a.o; List of Veterinary Drugs SPOFA 1983). Simultaneous action of the two drugs in poultry appears therefore quite possible in the field. Moreover, phenobarbital is one of substances modifying the action of a number of biologically active substances, particularly by induction of biotransformation enzymes (Květina and Fendrich 1978 a.o.). 
In spite of the rather numerous data on interactions of phenobarbital, or barbiturates in general, with a number of other drugs no studies have been published, to our knowledge, on interaction between phenobarbital and sulphadimidine in the domestic fowl (Gallus domesticus) in relation to age.

Berecký and Lopuchovský (1979) recorded effects of phenobarbital on sulphadimidine kinetics in white mice only after repeated phenobarbital administration which produced a decrease of sulphonamide concentration in the blood and some tissues. In our previous studies no changes were found in sulphadimidine blood levels of phenobarbital-premedicated mice of different ages (Sim ůnek 1974) but the toxicity of phenobarbital was increased by interaction with sulphadimidine particularly in young animals (Šim ůnek et al. 1985).

As to sulphonamides, there is ample evidence of negative effects of intervention on the mechanism of their antimicrobial action resulting in their impaired efficiency (PABA and derivatives) as well as of positive effects of intervention including the possibility of mutual combinations, combination with antibiotics and potentiation of their action (co-trimoxazol) (Śimunek a.o. as cited by Bentz 1982).

\section{Materials and Methods}

A total of 510 cockerels, line $\mathrm{H} \times \mathrm{SL}$ (Xaverov), were included in the experiments. They were 7, 28 and 49 days old and were grouped according to their age. Each of the three groups were divided into two premedicated subgroups and one subgroup receiving no premedication. The premedication consisted of intramuscular injection of sulphadimidine sodium salt in aqueous solution at the dose of $0.2 \mathrm{~g} / \mathrm{kg}$ body mass 15 or 120 minutes before phenobarbital administration. Aqueous solutions of phenobarbital (phenobarbitalum natricum pulv.) prepared immediately before use were injected i.m. in 10- or $20-\mathrm{mg} / \mathrm{kg}$-graded doses to 8 groups of 7 cockerels each. Prior to injection the concentrations of all solutions were adjusted so that the respective doses of the drugs were contained invariably in $1 \mathrm{ccm}$. The chickens were fed a commerical feed mixture $(\mathrm{K})$ with wheat supplements and had drinking water available ad libitum. Before being medicated, they were deprived of food for 12 hours.

All groups were observed for signs of intoxication and lethal effects up to 24 hours after phenobarbital administration. $\mathrm{LD}_{50}$ values were determined according to Litchfield and Wilcoxon (1949).

\section{Results}

Marked clinical signs of depression of the central nervous system (CNS) were observed as early as 30 minutes after phenobarbital administration, being particularly intense in birds premedicated with sulphadimidine 15 minutes previously, and receded

Table 1.

$L_{50}$ values of phenobarbital administered intramuscularly alone and after Na-sulphadimidine premedication ( $0.2 \mathrm{~g}$ per $\mathrm{kg}$ body mass) in cockerels of different ages

\begin{tabular}{|c|c|c|c|}
\hline \multirow{3}{*}{$\begin{array}{l}\text { Age } \\
\text { in days }\end{array}$} & \multicolumn{3}{|c|}{$\mathrm{LD}_{\mathrm{b0}}$ in $\mathrm{mg} / \mathrm{kg}$} \\
\hline & \multirow{2}{*}{$\begin{array}{l}\text { Without } \\
\text { premedication }\end{array}$} & \multicolumn{2}{|c|}{ After premedication } \\
\hline & & $15 \mathrm{~min}$ & $120 \mathrm{~min}$ \\
\hline 7 & $176^{(a)} \pm 11$ & $174^{(a)} \pm 10$ & $175^{(a)} \pm 12$ \\
\hline 28 & $\begin{array}{c}(c, d) \\
211^{ \pm}\end{array}$ & $\begin{array}{c}(a) \\
170^{ \pm}\end{array}$ & $\begin{array}{c}\text { (d) } \\
196^{ \pm} \pm 17\end{array}$ \\
\hline 49 & $242 \stackrel{\text { (b) }}{ \pm} 33$ & $\begin{array}{c}(b, c) \\
220 \pm 8\end{array}$ & $237^{(b)} \pm 22$ \\
\hline
\end{tabular}

Note. Values indicated by the same letters were not significantly different from one another. 
from 60 minutes to 6 hours after phenobarbital administration (in 7-day and 49-day-old chickens). In the remaining groups the occurrence of the signs of the CNS depression increased during the experiment. Deaths occurred, for the most part, after the 6th hour following phenobarbital administration in all experimental groups. The acute toxicity of phenobarbital was increased by sulphadimidine premedication only in chickens aged 28 and 49 days and particularly in the subgroups premedicated with sulphadimidine 15 minutes before phenobarbital administration. The results are presented in Table 1.

\section{Discussion}

In the present study both sulphadimidine and phenobarbital were administered by the intramuscular route. This mode of administration does not correspond to the use of the two drugs in poultry in the field and was chosen here to make possible interactions at the pharmacokinetic phase level more likely to be detected. This approach excludes the possibility of the results being affected by gastrointestinal resorption and eliminates interactions at the pharmaceutical level.

The experiments with cockerels of different ages showed that phenobarbital toxicity was higher for the younger birds irrespective of sulphadimidine premedication. To our knowledge, no data have been published on the $\mathrm{LD}_{50}$ of phenobarbital for the domestic fowl. A project report on SedophenR, a sedative premix for poultry, Ševčík (1973) described an unsuccessful attempt to determine the oral $\mathrm{LD}_{50}$ of phenobarbital alone and in combination with ascorbic acid $(2: 1)$ in vehicle (ad 500) in Sedophen ${ }^{\mathrm{R}}$ suspended in Dorfman's agent and administered to cockerels of 120 to $180 \mathrm{~g}$ in body mass. The highest possible quantity administered containing $900 \mathrm{mg}$ phenobarbital per $\mathrm{kg}$ body mass produced only occasional deaths in White Leghorn cockerels aged 21 days. In our experiments the $\mathrm{LD}_{50}$ of phenobarbital could be determined thanks, no doubt, to the intramuscular route of administration and, consequently, also to the use of phenobarbital sodium salt which is to be regarded as more toxic than phenobarbital itself. In our view, the data reported by S ev čík (1973) cannot be used for any comparison regarding phenobarbital toxicity because this investigator attempted to assess the toxicity of a phenobarbital-containing premix which comprised a considerable quantity of vitamin $C$ and a not specified vehicle, which might have affected phenobarbital action on the body. Moreover, this sedative premix, Sedophen ${ }^{\mathrm{R}}$, was suspended in Dorfman's agent which itself cannot be regarded a priori as pharmacologically inactive and still less as having no pharmaceutic activity when used in combination with other drugs. Not even the fact that the $\mathrm{LD}_{50}$ of phenobarbital in Sedophen ${ }^{\mathrm{R}}$ as determined by S evčík (1973) for rats upon oral administration in Dorfman's agent $(760 \mathrm{mg} / \mathrm{kg}$ ) was claimed by him to be in reasonable agreement with the dose reported in relevant literature $(660 \mathrm{mg} / \mathrm{kg}$ ) makes any difference; in point of fact, the latter dose is valid for sodium salt of phenobarbital ( $\mathrm{Sch}$ affarick and Brown as cited by Windholz 1976);

On the other hand, the observation of Lindau regarding higher sedative dose levels for birds than for mammals, which was quoted by Š evčík (1973) as supportive evidence, was confirmed by our experimental data in a previous study ( $S_{\text {im }}$ únek et al. 1976). Intramuscular administration of phenobarbital to chickens produced slight sleep at $80 \mathrm{mg}$ per $\mathrm{kg}$ body mass and only discontinous sleep of shorter duration when given at $40 \mathrm{mg}$ per $\mathrm{kg}$ body mass. These effects were age-dependent, with young chickens being more susceptible than the older ones. The doses per $\mathrm{kg}$ body mass were approximately one half of the pro toto doses used to produce sleep in man. The afore- 
mentioned previous experiments in our laboratory showed in addition that the classification of barbiturates according to duration of their action in man does not hold for the domestic fowl: allobarbital, e. g., acted markedly longer than phenobarbital when the two barbiturates were given in equal doses to chickens, whereas in man where therapeutic doses of allobarbital and phenobarbital are also equal it is the latter that acts longer.

In the present study the interaction of phenobarbital with sulphadimidine was manifested by increased barbiturate toxicity in 28- and 49-day-old chickens but no difference was observed in birds aged 7 days. The fact that the changes were more pronounced in those groups where the interval between administration of the drugs was shorter suggests a competitive mechanism of interaction by which the quantity of biologically available phenobarbital is increased. This in fact emerges from our results although it is well established that interactions of pharmaceuticals with phenobarbital or barbiturates depend, for the most part, upon enzyme induction. In consequence, substances administered with phenobarbital are subject to enhanced and accelerated biotransformation whereby their efficiency is reduced. Sulphonamides generally do not produce particularly rigid bonds in their competitive reactions so that they are often displaced by other drugs.

Deaths that occurred in our experiments were invariably associated with typical depression of the CNS. This indicates, no doubt, that the action of phenobarbital was increased by interaction with sulphadimidine. However, not even the possibility of a synergistic action of phenobarbital and sulphonamide can be entirely excluded. In our previous experiments with domestic fowls (Simủnek 1974) we recorded a biphasic action of sulphonamide, with the CNS depression (e. g. somnolence) occurring in the first phase. The mechanism of concurrent action of phenobarbital and sulphadimidine remains an open question and its elucidation requires further experimental studies.

\section{Vliv sulfadimidinu na toxicitu fenobarbitalu u rozdílně starých kuřat}

U kohoutků starých 7, 28 a 49 dní byla stanovena akutní intramuskulární toxicita sodné soli fenobarbitalu $\left(\mathrm{LD}_{50}\right)$ samotné, a po premedikaci sodnou soli sulfadimidinu (im. $0,2 \mathrm{~g} / \mathrm{kg}$ ž. h.) 15 , resp. 120 minut před podáním fenobarbitalu.

Akutní toxicita fenobarbitalu se s přibývajícím věkem kuřat snižovala. Premedikace sulfadimidinem u 7-denních kuřat neměla vliv na akutní toxicitu fenobarbitalu, u kuřat 28- a 49-denních byla toxicita oproti nepremedikovaným vyšší, zvláště při podání sulfadimidinu 15 minut před aplikací fenobarbitalu, a to u 28-denních kuřat statisticky významně.

Při sledování příznakủ útlumu do 24 hodin po aplikaci fenobarbitalu byly zjištěny rozdíly mezi věkovými skupinami, kdy u nejstarší skupiny byly velice intensivní, zvláště po premedikaci sulfadimidinem (15 minut):

\section{Влияние сульфадимидина на токсичность фенобарбитала у цыплят разного возраста}

У петушков в возрасте 7, 28 и 49 суток определяли острую интрамускулярную токсичность натриевой соли фенобарбитала (LD50) собственной и после премедикации натриевой солью сульфадимидина (интрамускулярно 0,2 г/кг живого веса) 15 или 120 минут перед подачей фенобарбитала. 
Острая токсичность фенобарбитала с возрастом цыплят понижалась. Премедикация сульфадимидином у цыплят в возрасте 7 суток не оказывала влияния на острую токсичность фенобарбитала, у цыплят в возрасте 28 и 49 суток токсичность по сравнению с цыплятами без премедикации была выше, в особенности перед подачей сульфадимидина за 15 минут перед вводм фенобарбитала, а именно у цыплят в возрасте 28 суток статистически значимо.

При наблюдении за признаками затихания до 24 часов после приема фенобарбитала была выявлена разница между возрастными группами, когда у группы самого старшего возраста признаки были самые интенсиьные, в особенности после премедикации сульфадимидином (15 минут).

\section{References}

BENTZ, H. (Hrsg.): Veterinärmedizinische Pharmakologie. VEB Gustav Fischer Verlag Jena 1982,676 p. (p. 440 ad.).

BERECKÝ, I. - LOPUCHOVSKÝ, J.: Ovplyvnenie farmakokinetiky sulfadimidinu niektorými látkami. Biol. - chem. - Vet., 15, 1979: 341 - 351.

KVĚTINA, J. - FENDRICH, Z.: Farmakologické interakce. Pokroky ve farmacii 1:11-108 Avicenum Praha 1978.

LITCHFIELD, J. T. Jun. - WILCOXON, F. W.: A simplified method for evaluating dose-effect experiments. J. Pharm. exptl. Ther., 96, 1949: 99-113.

Seznam veterinárních přípravkủ SPOFA, VÚBVL-OKVVI Pohoři - Chotouñ 1983, p. 352 (p. 214až 215, 225-227).

ŠEVĆíK, B. Sedophen - sedativní premix pro drůbež. Project report VÚBVL SPOFA 1973, p. 127.

ŠIMƯNEK, J.: Problematika dosologie léčiv $\mathrm{v}$ souvislosti s ontogenetickými změnami u zviřat zejména se zřetelem $\mathrm{k}$ sulfonamidưm. DrSc. thesis VŠV Brno 1974, $239 \mathrm{p}$.

ŠIMƯNEK, J.: Obecná farmakologie pro studující veterinární medicíny. Skript SPN Praha $1980,106 \mathrm{p}$.

ŠIMƯNEK, J. - HEGEROVÁ, E. - JAROŠ, J. - TKADLEC, E.: Effects of sulphadimidine on the toxicity of phenobarbital, pentetrazole and bemegride in mice of different ages. Acta vet. Brno 54, 1985: 177-182.

ŠIMƯNEK, J. - ŠVEC, J. - HEGEROVA, E. - JAROŠ, J. - JANCKE, S.: Účinnost některých barbituranů u kuřat rozdilného věku. Vet. Med. (Praha) 21, 1976: 229-235.

VODRÁŽKA, J. - MOZGOV, I. Je. - ŠIMU゚NEK, J.: Veterinárna farmakológia. Príroda Bratislava 1980, 436 p. (p. 73-74).

WINDHOLZ, M. (Edit.): The Merck Index, 9th ed. Merck and Co Inc. Rahway N. J. 1976. 